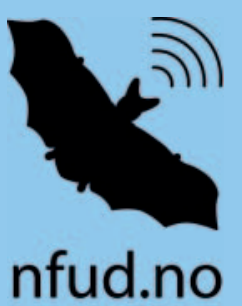

\section{NFUDs 43. symposium}

NFUD hadde sitt 43. symposium 3.-5. april. Møtet ble arrangert i Trondheim på Scandic Lerkendal. Siden symposiet denne gangen ble holdt i Norges teknologihovedstad var en av fellesesjonene dedikert det som kanskje kan bli fremtidens ultralyd; ultralyd i overvåkning, maskinlæring og kunstig intelligens.

Det var også i år rikelig med muligheter for å praktisert ultralyd med god tilgang på modeller, instruktører og ikke minst tilgang på en står maskinpark takket være flere påmeldte ultralydfirma.

I en forening med et så bredt publikum er det vanskelig å lage et fellesprogram som fenger alle. Det som forener medlemmene er imidlertid interesse for utviklingen av nye ultralydteknikker og interessen for å bruke ultralyd både til diagnostisere, men også til å styre behandlingen. Den siste dagen var hele programmet felles og fokuset var bruk av intravenøs ultralydkontrast samt ulike fagfelts bruk ultralyd i oppfølgingen av pasienter.

Prisen for beste frie foredrag på $10000 \mathrm{kr}$ ble vunnet av Johannes Kvam fra Institutt for sirkulasjon og bildediagnostikk ved NTNU for sitt foredrag "Characterization of tissue based on nonlinear bulk elasticity with dual frequency ultrasound». Ved å analysere den non-lineære komponenten ved akustisk kompresjon kan man få frem en parameter som kanskje kan vises seg å være bedre til å skille sykt og friskt vev enn elastografi. Kasuistikkprisen på 5000 kr gikk til Vibeke Skoura-Torvik ved Nasjonal behandlingstjeneste for avansert invasiv fosterdiagnostikk ved St. Olavs Hospital for presentasjonen: «Muskulær ventrikkel septum defekt.» Øyvind Johannesen ble tildelt Forskningsstipendet på kr. 10000 ,- for sitt

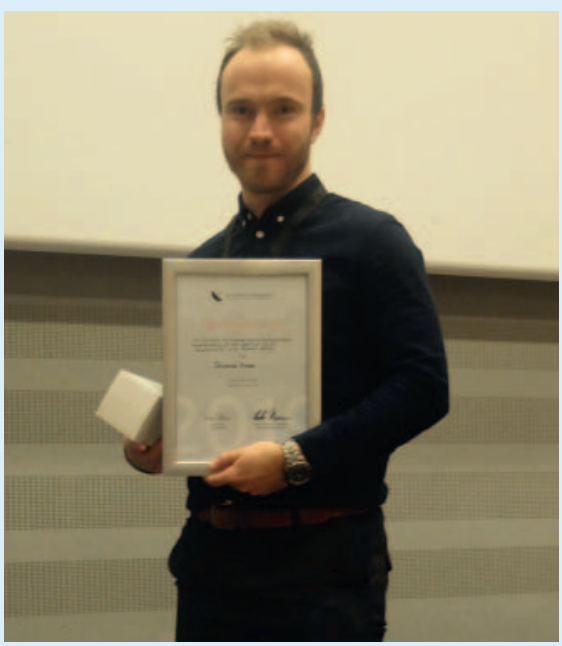

Johannes Kvam

prosjekt: "Lung ultrasound as a novel tool to discover pulmonary congestion in patients with COPD.» Styret gratulerer alle prisvinnerne.

På generalforsamlingen dominerte valget som tema. Hele det sittende styret gikk og ble byttet ut med nye krefter. Valgkomiteen bestod av Roald Flesland Havre (leder), Hilde Berner Hammer, Bjørn Angelsen, Claudia Heien og Vivi Bakkeheim. Det nye styret i NFUD består nå av:

- Vibeke Torvik Jordmor ved Norsk Senter for Fostermedisin (NSFM), St. Olavs Hospital

- Solveig Fadnes, sivilingeniør ved Inst. for sirkulasjon og bildediagnostikk, NTNU

- Maria von Krogh, LiS i revmatologi ved Diakonhjemmet Oslo

- Bjarte Sørensen, Spesialist i allmennmedisin, Hjelmeland i Rogaland

- Karin Ulrike Deibele, obstetriker ved NSFM, St Olavs Hospital.

- Victoria Vatsvåg, sonograf, Stavanger.

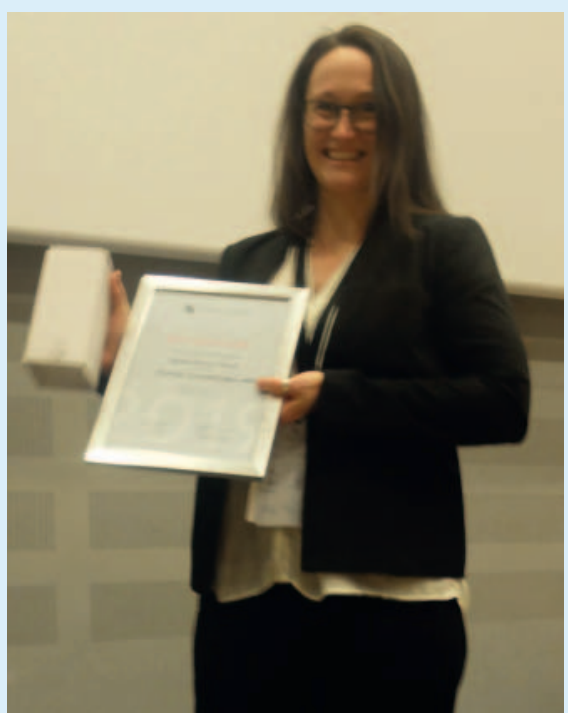

Vibeke Skoura-Torvik

- Lars Petter Bache Wiig Bjørnsen, overlege ved klinikk for akutt og mottaksmedisin, St. Olavs hospital

- Anesa Mulabecirovic tilknyttet Nasjonal kompetansetjeneste for gastroenterologisk ultrasonografi ved Haukeland Universitetssjukehus ble valgt som leder.

Morten Glasø ble valgt som revisor. Det kom også frem at foreningen har en sunn økonomi, gikk i overskudd ved symposiet i Stavanger i 2018 og høyst sannsynlig vil gå med overskudd når regnskapet er gjort opp etter årets symposium i Trondheim. NFUD takker det avgåtte styret for innsatsen.

Det var ellers gledelig at symposiet i Trondheim ble svært godt besøkt med over 150 deltagere. Neste år vil symposiet bli en del av Euroson 2020 i Bergen og alle tidligere deltagerekorder forhåpentligvis bli ettertrykkelig knust. Velkommen til Bergen! 